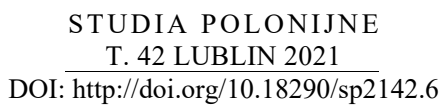

TOMASZ NOWICKI

\title{
POLSKIE PIESZE PIELGRZYMKI Z ESSEN DO NEVIGES W LATACH 1981-2005
}

Pielgrzymowanie (łac. peregrinatio), zwane też po polsku pątnictwem, to forma religijności znana $\mathrm{w}$ chrześcijaństwie (również $\mathrm{w}$ religiach niechrześcijańskich), polegająca na podejmowaniu podróży do miejsc uważanych za święte. Motywem takiej wędrówki są względy religijne takie, jak chęć zadośćuczynienia za popełnione grzechy, wyrażenia prośby lub podziękowania. Zgodnie $\mathrm{z}$ definicją, by zrealizować $\mathrm{w}$ pełni pielgrzymkę, potrzebne są trzy elementy. Po pierwsze - konieczne jest „wyjście z domu” na wzór wędrówki Abrahama i Izraelitów z Ur Chaldejskiego przez pustynię do Ziemi Obiecanej. Po drugie - potrzebna jest „droga”. Po trzecie - konieczny jest „cel”. Pielgrzymowanie wymaga wyrzeczeń, wysiłku fizycznego, niejako daru z siebie i ze swojego czasu. Stanowi wyraz pobożności, jest czasem pokuty i modlitwy ${ }^{1}$.

W Nowym Testamencie wzór pątnictwa stanowi pielgrzymka odbyta przez Świętą Rodzinę do Jerozolimy na doroczne obchody Paschy. W chrześcijaństwie tradycje pielgrzymowania sięgają czasów starożytnych. Szczególnie można to zauważyć od IV wieku, kiedy chrześcijanie przestali być prześladowani i mogli swobodnie wyznawać swoją wiarę. Pielgrzymowanie do miejsc świętych, zwłaszcza związanych z życiem i działalnością Jezusa w Palestynie, stawało się wówczas coraz bardziej popularne. W późniejszych wiekach coraz częstsze stawały się pielgrzymki do innych miejsc, np. do grobów świętych i kościołów z relikwiami. Na Zachodzie pielgrzymowano do grobów apostołów w Rzymie czy w Santiago de Compostela. W późnym średniowieczu rosła popularność pielgrzymowania do sanktuariów powstałych

Dr hab. TOMASZ NowICKI, prof. KUL - dyrektor Instytutu Historii na Wydziale Nauk Humanistycznych Katolickiego Uniwersytetu Lubelskiego Jana Pawła II; e-mail: tomasz.nowicki@kul.pl; ORCID: https://orcid.org/0000-0003-1185-9358.

${ }^{1}$ Z. PaŁubSKA, Pielgrzymowanie, [w:] Encyklopedia Katolicka, t. XV, Lublin 2011, kol. 501. 
W związku z rozwojem kultu eucharystycznego. Już w tej epoce pojawiły się również pierwsze maryjne miejsca pielgrzymkowe ${ }^{2}$.

Tradycja pielgrzymowania do miejsc świętych w Polsce również sięga okresu średniowiecza. Jeśli chodzi o maryjne miejsca kultu, to do najstarszych należy krajeńska Górka Klasztorna (od XII wieku), śląskie Bardo i Wambierzyce oraz Lubawa w ziemi chełmińskiej (od XIII wieku). W późniejszych wiekach, szczególnie w okresie późnego średniowiecza i okresie nowożytnym nastąpił znaczący rozwój miejsc pielgrzymkowych. Rozwijała się tradycja pieszego pielgrzymowania do sanktuariów maryjnych. Na przełomie XIX i XX wieku najważniejszym ośrodkiem pielgrzymkowym stała się Jasna Góra, gdzie tradycja corocznych pieszych pielgrzymek znana była co najmniej od początku XVIII wieku. Szczególnie popularne stały się od lat siedemdziesiątych XX wieku³.

Nasi rodacy zamieszkujący wiele krajów świata, niejako przynosili ze sobą tę szczególną cechę polskiej religijności - pielgrzymowanie. Zwłaszcza warto zwrócić uwagę na specyficzną polską pobożność maryjną. Stąd w wielu miejscach świata, w wielu polskich ośrodkach duszpasterskich, jeśli nawet nie we wszystkich, obecny jest wizerunek Matki Bożej Częstochowskiej, a miejsca pielgrzymkowe, do których pielgrzymuje Polonia, często noszą nazwę nawiązującą do wizerunku Czarnej Madonny. Stąd można spotkać nazwy Amerykańska Częstochowa, Australijska Częstochowa, a także Westfalska (Niemiecka) Częstochowa ${ }^{4}$.

Do tej wielowiekowej tradycji pieszej wędrówki do sanktuarium maryjnego pragnęli nawiązać również inicjatorzy omawianej w niniejszym artykule pielgrzymki z Essen do Neviges. Zanim jednak przejdziemy do omówienia tego tematu, należy krótko omówić materiał źródłowy, będący podstawą artykułu. Dokumentacja omawiająca polskie piesze pielgrzymki z Essen do Neviges została przekazana do Archiwum Głównego Ruchu Światło-Życie w Lublinie przez p. Cezarego Lisa we wrześniu 2020 r. w trakcie pobytu w Ahaus (Niemcy) dra Roberta Derewendy, dyrektora Archiwum, oraz piszącego te słowa. Materiał ten został już wstępnie opracowany zgodnie z zasadami polskiej metodyki archiwalnej. W chwili obecnej obejmuje 18 teczek

\footnotetext{
${ }^{2}$ S. JABŁOŃSKI, Pielgrzymka, III. W chrześcijaństwie, [w:] tamże, kol. 485-491.

${ }^{3}$ Tamże, kol. 491-500.

${ }^{4}$ Por. M. GRYGIEL TCHR, Sanktuaria Maryjne na szlakach pielgrzymich Polonii, [w:] Bogurodzica na ludzkich drogach życia, red. B. Walicki, Sokołów Małopolski 2010, s. 202. O polskich pielgrzymkach do Neviges zob. tamże, s. 208-209.
} 
aktowych z lat 1981-20055. Materiały zostały ułożone chronologicznie według lat pielgrzymek począwszy od 1981 r., choć brak dokumentacji z niektórych roczników (1982, 1996, 1998, 2000 oraz 2001-2004). Różny jest również zakres rzeczowy materiałów, co jest związane z postępującym rozwojem organizacyjnym pielgrzymki. Należy też pamiętać, że archiwalia są pochodzenia osobistego i to od twórcy dokumentacji zależało, jaki zakres rzeczowy mają poszczególne roczniki. Warto też już w tym miejscu dodać, że od 1985 r. peregrynacje były prowadzone jako pielgrzymki Ruchu Światło-Życie. Ostatnie dokumenty zgromadzone w serii dotyczącej pieszych pielgrzymek z Essen do Neviges dotyczą jubileuszowej 25. pielgrzymki odbytej w dniach 18-19 czerwca 2005 r. Być może była to ostatnia peregrynacja przygotowana przez środowiska związane z ruchem oazowym i ośrodkiem w Carlsbergu. Można tylko przypuszczać, że w kolejnych latach pielgrzymka piesza z Essen była już organizowana przez Księży Chrystusowców polskiej parafii w Essen i obok innych pieszych peregrynacji do Neviges została włączona do oficjalnych uroczystości związanych z Polską Pielgrzymką do Sanktuarium Matki Bożej Królowej Pokoju6. W każdym razie na roku 2005 kończy się dokumentacja przekazana do Archiwum Głównego w Lublinie przez Cezarego Lisa.

Przekazane archiwalia występują przede wszystkim w postaci dokumentacji papierowej w formie rękopisów, maszynopisów, kserokopii i wydruków komputerowych, a także w formie fotograficznej (odbitki pozytywowe). Niekiedy dołączone są emblematy pielgrzymkowe malowane na tkaninach oraz broszury, a wyjątkowo także plastykowe znaczki.

Tradycje pielgrzymowania do sanktuarium w Neviges sięgają drugiej połowy XVII wieku. Wieś należała do rodu Hardenbergów. W dobie reformacji właściciele osady przyjęli kalwinizm. Kiedy w XVII wieku Johann Sigmund von Bersnasau, właściciel Neviges, powrócił do wyznania katolickiego, protestantyzm był już na tyle silny w okolicy, że po jego śmierci nie można było odprawić katolickiego nabożeństwa pogrzebowego w kościele parafialnym. W tej sytuacji wdowa Anna von Ansbek postanowiła w 1670 r. wybudować na obrzeżu miejscowości osobny kościól, nad którym opiekę w 1676 r. przekazała franciszkanom. Według podań, jednemu z nich, przebywającemu

\footnotetext{
${ }^{5}$ Archiwum Główne Ruchu Światło-Życie, zespół: Spuścizna archiwalna Cezarego Lisa, seria: Kronika pieszej pielgrzymki Essen-Neviges 1981-2005 [dalej: Kronika].

${ }^{6} \mathrm{~W}$ dokumentacji jedynym śladem takiej zmiany jest zachowany w zespole folder opracowany już przez Księży Chrystusowców przy okazji Polskiej Pielgrzymki do Neviges w dniach 16-17 czerwca 2012 r. W folderze jest również informacja o pieszych pielgrzymkach z Düsseldorfu, Essen, Bochum, Wuppertalu, Remscheid i Duisburga (zob. Kronika, sygn. 18, s. 71).
} 
w klasztorze w Dortsen (około $50 \mathrm{~km}$ na północ od Neviges), ukazała się Matka Boża na niedużym obrazku i poleciła, aby go przeniósł do nowego klasztoru. Ten obrazek do dzisiaj czczony jest w sanktuarium w Neviges? ${ }^{7}$

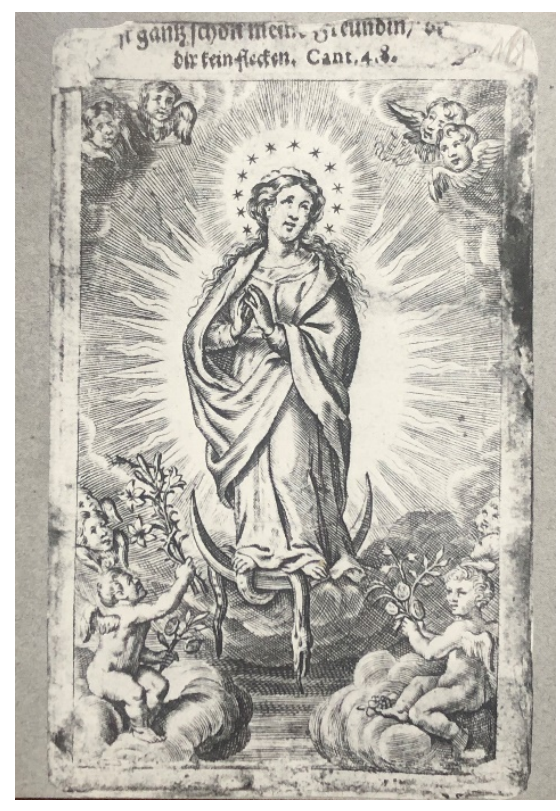

Kronika, sygn. 18, s. 20

Z kolei początki pielgrzymowania do nowego ośrodka kultu maryjnego w Westfalii związane są $\mathrm{z}$ osobą księcia-biskupa Paderborn Ferdynanda von Fürstenberga. Cudownie uzdrowiony z ciężkiej choroby, ślubował przybyć na pielgrzymkę dziękczynną do Neviges. 25 października 1681 r. w kościele św. Anny w obecności księcia Berga i opata Werden odprawił pontyfikalną mszę. To wydarzenie zapoczątkowało kult maryjny i stopniowy rozwój ruchu pielgrzymkowego. Szczególny wzrost pobożności maryjnej nastąpił po ogłoszeniu dogmatu o Niepokalanym Poczęciu Maryi w 1854 r. Do westfalskiego sanktuarium pielgrzymowało coraz więcej wiernych. W niektórych latach jednorazowo liczba pielgrzymów przekraczała 10 tys. osób, a bywały także dni, kiedy ich dzienna liczba sięgała nawet 40 tys. Podobnie było w latach międzywojennych XX wieku. Już wówczas zamierzano rozbudować świąty-

\footnotetext{
${ }^{7}$ Por. G. Haun, Die Wallfahrt nach Neviges, Wuppertal 1981; M. GRYGIEL TCHR, Sanktuaria Maryjne..., s. 208-209; zob. Kronika, sygn. 18, s. 5, 16, 23-26; por. K. WeSOLY, Velbert, Neviges und Langenberg vom früher Mittelalter bis zum Ende bergischen Zeit (1806), [w:] VelbertGeschichte dreier Städte, Hrsg. H. Degen, Ch. Schotten, Köln 2009, s. 61-63.
} 
nię, jednak okres rządów Hitlera, a następnie wojna uniemożliwiły realizację tych projektów. Po II wojnie światowej liczba pielgrzymów była nadal liczna. Dopiero na początku lat sześćdziesiątych powrócono do pomysłu budowy nowej świątyni. Zrealizowano go w ciągu dziesięciu lat. Nową świątynię (tzw. Mariendom) zbudowano na podstawie projektu architekta Gottfrieda Böhma z Kolonii i jest to koncepcja oparta na popularnym w tamtym czasie nurcie brutalizmu w architekturze. Bryła budowli w kształcie nieregularnej figury o długości $50 \mathrm{~m}$ i szerokości $37 \mathrm{~m}$ zajmuje powierzchnię około $2000 \mathrm{~m}^{2}$. Dach w kształcie trzech zachodzących na siebie betonowych namiotów wznosi się w najwyższym miejscu na wysokość 34 metrów. Symbolicznie budowla ma być widocznym znakiem kościoła pielgrzymkowego. W architekturze wewnętrznej i zewnętrznej zawiera wiele symbolicznych elementów nawiązujących do Biblii i liturgii. Centralnym miejscem kultu jest kaplica z czterometrowym słupem, na którym umieszczony jest cudowny obraz Matki Bożej Królowej Pokoju

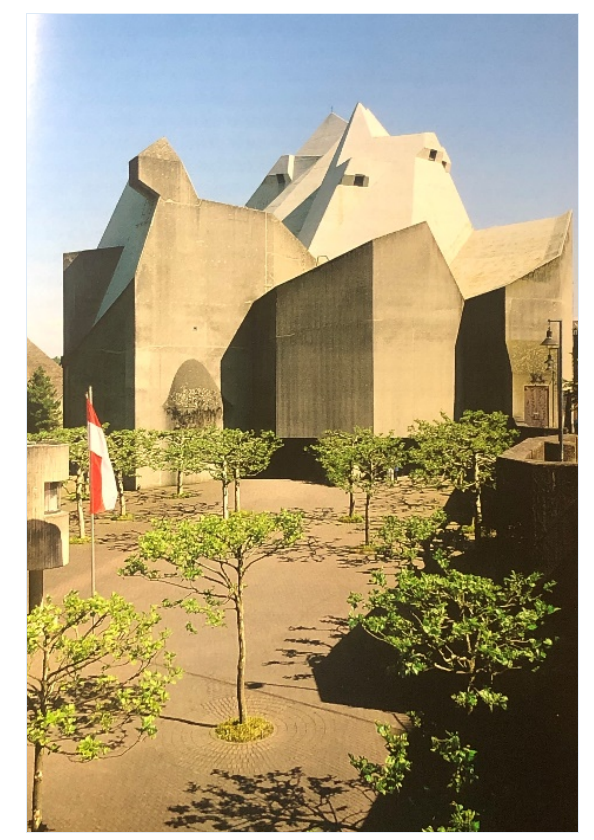

Kronika, sygn. 18, s. 29

${ }^{8}$ Zob. G. HAUn, Mariendom Neviges, Lindenberg 1997; por. M. GRYGIEL TCHR, Sanktuaria Maryjne..., s. 208-209; Kronika, sygn. 18, s. 6-11, 16, 27nn; por. Mariendom „Maria, Königin des Friedens", https://www.wallfahrt-neviges.de/index.php/wallfahrt/mariendom [dostęp: 10.03.2021]. 
Wróćmy jednak do omówienia początków polskich pieszych pielgrzymek z Essen do Neviges. Od lipca i sierpnia 1980 r. w całej Polsce wybuchały strajki mające charakter pokojowych demonstracji, często z Mszą świętą, krzyżami, modlitwą i zdjęciami Jana Pawła II. Wkrótce powstała „Solidarność”. Wydarzenia te obudziły wielkie nadzieje na zmiany w kraju. Do Częstochowy na Jasną Górę szły liczne pielgrzymki z całej Polski, z każdej niemal polskiej diecezji. Pątnicy z modlitwą i śpiewem na ustach przemierzali kraj niosąc biało-czerwone sztandary i transparenty z emblematami „Solidarności”. Wówczas to w środowisku skupionym w młodzieżowej wspólnocie w Essen zrodził się pomysł, by zorganizować w imię solidarności z rodakami w kraju pieszą pielgrzymkę z Essen do Neviges ${ }^{9}$.

Trzeba w tym miejscu dodać, że Neviges, jako miejsce pielgrzymek, już wcześniej było nawiedzane przez mieszkających w Niemczech Polaków. Tradycja polskich pielgrzymek do westfalskiego sanktuarium sięga ponad stu lat ${ }^{10}$. Jeszcze w XIX wieku wielu z nich przyjeżdżających w poszukiwaniu pracy do Zagłębia Ruhry odwiedzało Neviges. O znaczeniu miejsca dla niemieckiej Polonii świadczy fakt, że od wielu lat nazywane było właśnie westfalską Częstochową. Po drugiej wojnie światowej Polacy pielgrzymowali do Neviges już w 1947 r. ${ }^{11}$ W późniejszych latach Polacy przyjeżdżali corocznie do Neviges w każdą trzecią niedzielę czerwca. Ten termin był już tradycyjnie wyznaczony na pielgrzymki niemieckiej Polonii. Warto również dodać, że w pielgrzymkowej świątyni znajduje się wizerunek Jasnogórskiej Królowej Polski ofiarowany w 1978 r. przez kard. Stefana Wyszyńskiego, który odwiedził to miejsce objawień. 28 września 1978 r., czyli kilka tygodni przed wyborem na papieża, z pielgrzymką w Neviges był również kard. Karol Wojtyła ${ }^{12}$.

Jak już wspomniano, początki pierwszej polskiej pielgrzymki pieszej z Essen do Sanktuarium Maryjnego w Neviges ${ }^{13}$ sięgają roku 1981 i związane

\footnotetext{
${ }^{9}$ C. Lis, Piesze pielgrzymowanie do Neviges, https://cezarylis.pl/25-piesze-pielgrzymowaniedo-neviges/ [dostęp: 9.04.2021]; por. Kronika, sygn. 18, s. 76.

${ }^{10}$ Zob. K. MuRZYNOwSKA, Polskie wychodźstwo zarobkowe w zagłębiu Ruhry w latach 18801919, Wrocław 1972, s. 187.

${ }^{11}$ Te pierwsze po wojnie spotkania Polaków współorganizował m.in. chrystusowiec ks. Józef Okos, który od 1952 r. był przełożonym domu zakonnego w Essen. Por. L. PASzeK, Historia Polskiej Misji Katolickiej w Essen, http://www.pmk-essen.de/index2.php?id=historia [dostęp: 24.03.2021] .

${ }^{12}$ Kronika, sygn. 18, s. 16, 59-60; Piesza Pielgrzymka Polaków do Neviges, https://www. chrystusowcy.pl/piesza-pielgrzymka-polakow-do-neviges [dostęp: 10.03.2021]

${ }^{13}$ Dzisiejsza oficjalna nazwa miejscowości to Velbert. Miasto znajduje się w kraju związkowym Nadrenia Północna-Westfalia, w rejencji Düsseldorf, w powiecie Mettmann, w regionie Bergisches Land. Neviges jest częścią tej jednostki administracyjnej. Do jej utworzenia doszło
} 
są z działalności Cezarego Lisa w Stowarzyszeniu Katolików Polskich w Niemczech „Polonia Semper Fidelis”, założonym i prowadzonym przez inż. J. Szpondera z Moers. Mieszkając wówczas w Essen, C. Lis przy Polskiej Misji Katolickiej prowadzonej przez Księży Chrystusowców (m.in. ks. W. Przybylski) założył w 1981 r. duszpasterską grupę młodzieżową. Wspólnota młodych polskich katolików spotykała się w kilkunastoosobowym zespole regularnie co tydzień ${ }^{14}$. Pomysłodawca spodziewał się spontanicznego poparcia, lecz spotkało go małe rozczarowanie. Padały głosy, że nie ma to sensu, że pieszo nikt w Niemczech nie chce pielgrzymować, skoro można łatwo dojechać autem lub pociągiem, że generalnie nie ma w Niemczech tradycji pieszego pielgrzymowania, takiej jak w Polsce. Podobnie sceptycznie ustosunkował się do pomysłu proboszcz, odmawiając prośbie poinformowania o tej inicjatywie na Mszy św. Pomimo tych przeciwności ostatecznie udało się zebrać grupę siedmiu osób ${ }^{15}$, które postanowiły iść pieszo z Essen do Neviges, by wziąć udział w corocznej polskiej pielgrzymce do westfalskiej Częstochowy. Od tej pierwszej, spontanicznie i oddolnie zorganizowanej pielgrzymki datowane są wszystkie następne organizowane do dzisiaj.

Jak wspomniano, termin, który wybrano, był związany z organizowanymi już wcześniej peregrynacjami Polonii do Neviges. Nie były to jednak wyprawy piesze, lecz pielgrzymki zorganizowane przez Polską Misję Katolicką w Niemczech. Przykładowo - z ulotki opracowanej przez komitet organizacyjny polskiej pielgrzymki poznajemy program z $1981 \mathrm{r}$. Przewidywał on wydarzenia tylko na niedzielę 21 czerwca i w zasadzie obejmował trzy elementy. O 9:30 zebrani mieli wejść procesyjnie do bazyliki pielgrzymkowej, o 10:00 była przewidziana Msza św., zaś o 15:00 miała się odbyć procesja na pobliską Górę Maryi oraz nabożeństwo maryjne. Ten schemat oficjalnej pielgrzymki Polonii do Neviges zasadniczo powtarzał się także w kolejnych latach. Zmieniały się ewentualnie godziny poszczególnych nabożeństw ${ }^{16}$.

Pomysł pieszego wędrowania do sanktuarium, zainicjowany przez C. Lisa i środowisko młodzieży $\mathrm{z}$ Essen, nie był zatem oficjalnie włączony do

w 1975 r., kiedy połączono niezależne dawniej miasteczka Langenberg, Neviges i (stary) Velbert, tworząc miasto Velbert. Zob. W. Wohlmann, Die neue Stadt Velbert (1975-2008), [w:] Velbert Geschichte..., s. 482 nn; por. Kronika, sygn. 18, s. 5.

${ }^{14}$ Zob. C. Lis, Piesze pielgrzymowanie do Neviges, https://cezarylis.pl/25-piesze-pielgrzymo wanie-do-neviges/ [dostęp: 9.04.2021]; por. Kronika, sygn. 18, s. 76.

${ }^{15} \mathrm{~W}$ dokumentacji archiwalnej pojawia się także informacja, że w pierwszej pieszej pielgrzymce z Essen uczestniczyło 6 osób - na jednym ze zdjęć i w jego opisie autor Kroniki informował o sześciu osobach biorących udział w pieszej wyprawie do Neviges (Kronika, sygn. 1 [1981], s. 2-3).

${ }^{16}$ Kronika, sygn. 1 [1981], s. 1. 
programu polskiej pielgrzymki do Neviges. Była to całkowicie oddolna inicjatywa świeckich katolików, którzy postanowili pieszo dotrzeć do tej miejscowości na spotkanie z Maryją w sanktuarium i tam dołączyć do oficjalnego pielgrzymowania polskiej społeczności w Niemczech. Trzeba jeszcze dodać, że istniały inne podobne inicjatywy. Z Wuppertalu piesze peregrynacje organizował Piotr Siegfanz, z Düsseldorfu Zenon Kapela. Z czasem z grupy pielgrzymującej z Essen wyłoniła się grupa pątników wędrująca z Bochum. Szli oni równolegle tą samą trasą, prowadzeni przez księży z Polskiej Misji Katolickiej w Bochum ${ }^{17}$.

Analizując dokumentację archiwalną Kroniki o pieszym pielgrzymowaniu z Essen na spotkanie z Matką Bożą z Neviges począwszy od 1981 r., można powiedzieć, że inicjatywa ta miała wówczas charakter prywatnej modlitwy połączonej z charakterystycznym dla polskiej pobożności wędrowaniem do sanktuariów. Świadczą o tym liczby uczestników tej inicjatywy. W pierwszym roku, o czym była wyżej mowa, na pątniczy szlak ruszyło 7 osób. W 1982 r. szło pieszo tylko pięć, zaś w 1983 r. jedynie cztery. Można nawet przypuszczać, że gdyby ówcześni organizatorzy pieszych wypraw odeszli od tego pomysłu, być może inicjatywa ta nie byłaby kontynuowana. Wczytując się dokładnie w zachowaną dokumentację można zauważyć znaczącą zmianę, która następowała od 1984 r. Wówczas po raz pierwszy na pątniczy szlak wyruszyła grupa młodzieży oazowej pod przewodnictwem ks. diakona Kazimierza Ćwierza, który wspomógł organizacyjnie i duchowo pierwotnych pomysłodawców wędrówki z modlitwą. Włączenie się do inicjatywy zapoczątkowanej przez Cezarego Lisa środowiska oazowego skupionego wokół ks. Franciszka Blachnickiego w Carlsbergu wpłynęło zdecydowanie na dalszy rozwój pielgrzymki ${ }^{18}$. Od następnego roku, tj. od 1985, piesze wędrowanie z Essen do Neviges stało się już oficjalnie pielgrzymką prowadzoną przez Ruch Światło-Życie ${ }^{19}$.

\footnotetext{
${ }^{17}$ Potwierdza to relacja C. Lisa (zob. Kronika, sygn. 18, s. 76; https://cezarylis.p1/25-pieszepielgrzymowanie-do-neviges/ [dostęp: 9.04.2021]), a także sama dokumentacja. Na przykład wspólne zdjęcie z grupą z Wuppertalu w 1985 r. (zob. Kronika, sygn. 3 [1985], s. 15) czy też korespondencja z Zarządem Miejskim w Wuppertalu z 1988 r. (zob. Kronika, sygn. 6, s. 15).

${ }^{18} \mathrm{Z}$ tego roku zachowała się wprawdzie nieliczna dokumentacja (jedno zdjęcie kilkunastoosobowej grupy oraz ogólna ulotka zapraszająca Polaków do Neviges na coroczną pielgrzymkę Polonii, zawierająca po raz pierwszy informację o grupie pieszej z Essen). Potwierdza ona jednak wagę włączenia się w organizację środowisk oazowych w Niemczech. Zob. Kronika, sygn. 2 [1983-1984], s. 3 .

${ }^{19} \mathrm{Z}$ relacji Cezarego Lisa wynika, że zabiegał o to osobiście u ks. Franciszka Blachnickiego (zob. Kronika, sygn. 18, s. 76).
} 
Włączenie się środowiska oazowego do organizacji pielgrzymki przyczyniło się do zmian organizacyjnych. Zmieniono wówczas czas wyjścia. O ile $\mathrm{w}$ poprzednich latach wyruszano w drogę wczesnym rankiem w niedzielę, tak by dotrzeć na Mszę świętą dla Polonii organizowaną przez Polską Misję Katolicką, o tyle od 1985 r. wymarsz z Essen następował w sobotę do południa, tak by już wieczorem dotrzeć do Neviges i następnego dnia dołączyć do głównych uroczystości pielgrzymkowych. Zdecydowanie rosła również liczba pątników idących z Essen. W pierwszych pielgrzymkach z lat 1981, 1982, 1983 - jak już wspomniano - brało udział tylko kilka osób. Jednak już w 1984 r. grupa pielgrzymów liczyła 30 osób. W kolejnych latach liczba ta rosła, osiągając apogeum w 1994 r. Niestety, nie znamy dokładniejszych liczb z lat 1996-2005 ${ }^{20}$.

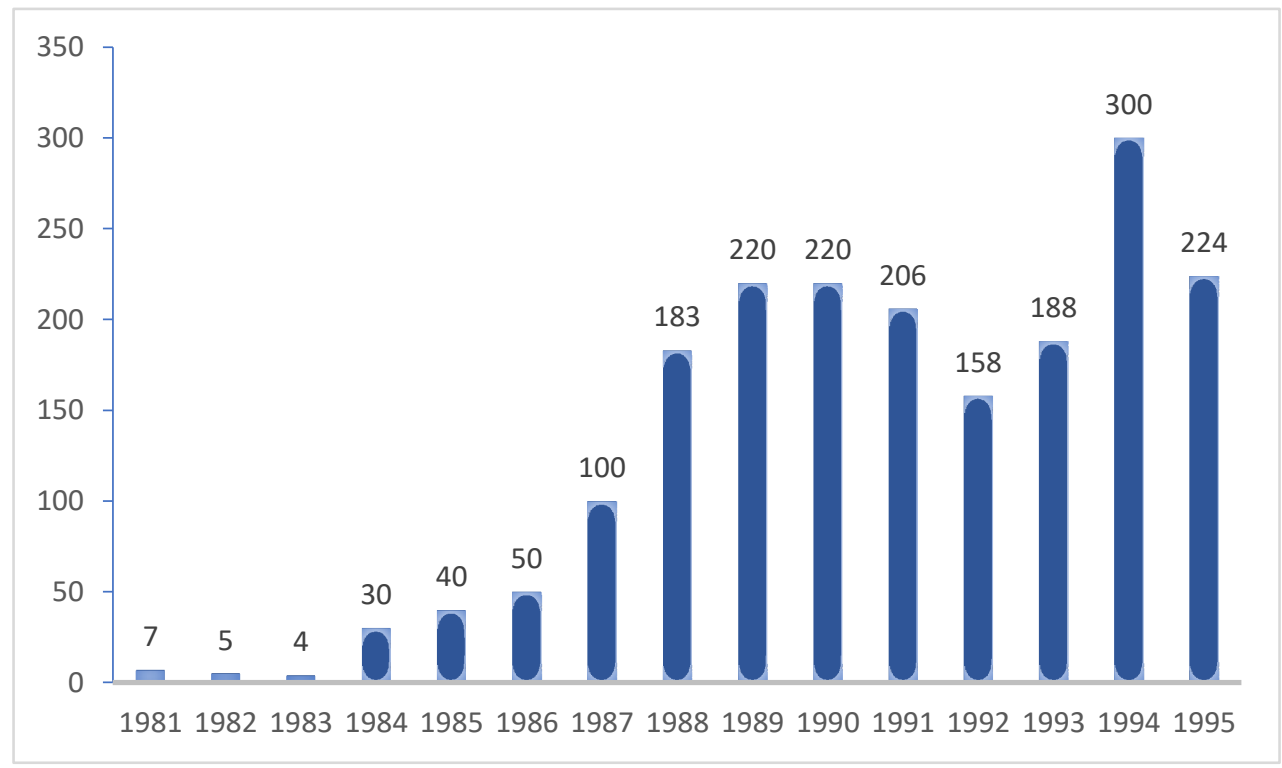

Wykres 1. Liczba osób biorących udział w pieszych pielgrzymkach z Essen do Neviges w latach 1981-1995

Rosła także liczba księży pielgrzymujących pieszo z Essen do Neviges. Wiadomo, że w 1985 r. z pielgrzymami wędrował ks. Ćwierz ${ }^{21}$, w 1986 r.

${ }^{20} \mathrm{Z}$ ogólnego podsumowania przygotowanego na potrzeby ulotki z 2005 r. wiadomo, że w tych latach przeciętnie brało udział około 100 osób (zob. Kronika, sygn. 18 [2005], s. 10).

${ }^{21}$ Zob. Kronika, sygn. 5 [1985], s. 3, 13. Ks. K. Ćwierz, jeszcze przed święceniami prezbiteratu, brał udział w pielgrzymce w roku poprzednim (zob. Kronika, sygn. 2 [1983-1984], s. 6). 
pielgrzymowało pieszo trzech kapłanów ${ }^{22}$, w 1988 - pięciu ${ }^{23}$, zaś w 1991 siedmiu ${ }^{24}$. Obok co roku uczestniczących w peregrynacjach członkiń wspólnoty Niepokalanej Matki Kościoła mieszkających Carlsbergu, w pielgrzymkach brały również udział siostry zakonne ${ }^{25}$. W pieszych peregrynacjach, przynajmniej tak wynika z danych z 1987, 1988 i 1995 r., przeważały kobiety. W dwóch pierwszych latach tylko nieznacznie, bo odpowiednio stanowiły 56 i $51 \%$. Z kolei z danych z 1995 r. wynika, że odsetek uczestniczek pieszych pielgrzymek był wyższy i wynosił $63 \%$. Nie wiadomo jednak, jak wyglądała ta relacja w innych latach.

Poza zwiększającą się liczbą uczestników, zauważyć można rosnącą liczbę miejsc, skąd przybywali pielgrzymi. Od 1985 r. w pieszym pielgrzymowaniu z Essen do Neviges brali udział polscy pielgrzymi z całych niemal Niemiec Zachodnich. Czasami, jak na przykład w 1989 r. w pielgrzymce, obok Polaków z Niemiec i z Polski uczestniczyła również grupa niemieckojęzyczna oraz dwójka pielgrzymów z Peru ${ }^{26}$. Dokładniejsze informacje o zamieszkaniu uczestniczących w peregrynacji pątników posiadamy z lat 1987, 1988, 1991, 1992 i 1995. Spójrzmy na to zagadnienie przez pryzmat niemieckich landów. Jak wynika z list uczestników, co nie powinno dziwić, najczęściej pielgrzymi zamieszkiwali Westfalię. Odsetek pielgrzymów zamieszkujących ten land wynosił 2/3 uczestników, jak miało to miejsce w 1987 i 1992 r. Osoby zamieszkujące Westfalię stanowiły niemal 75\% w 1995 r. Najbardziej urozmaicona, pod kątem pochodzenia pątników, była pielgrzymka z roku 1991. Wówczas z Westfalii było jedynie 48\% uczestników, a rok później ten odsetek wynosił 55\%. W trzech pierwszych analizowanych latach zwraca uwagę ponad $10 \%$ udział pielgrzymów z Palatynatu ${ }^{27}$. Tę liczną reprezentację tego landu wyjaśnia to, że właśnie na terenie tego kraju związkowego znajdowało się niemieckie centrum oazy w Carlsbergu. W miarę

${ }^{22}$ Obok ks. Ćwierza wzięli udział również ks. Ireneusz Kopacz i ks. Marek Dydo (zob. Kronika, sygn. 4 [1986], s. 12, 14).

${ }^{23}$ Księża: Ćwierz, Dydo, Kopacz i Jacek Herma z Carlsbergu oraz Sławomir Pitek z Essen (zob. Kronika, sygn. 6 [1988], s. 12).

${ }^{24}$ Obok uczestniczących w 1988 r. księży Ćwierza, Dydo, Kopacza i Hermy, w pielgrzymce brali również udział o. Stanisław Stój z Rzymu, nieznany z nazwiska ks. Tadeusz z Brunszwiku oraz ks. proboszcz z Osnabrück (zob. Kronika, sygn. 9 [1991], s. 7).

${ }^{25}$ Przykładowo w 1988 r. na pątniczy szlak wyruszyły trzy zakonnice ze Zgromadzenia Misjonarek Chrystusa Króla dla Polonii z przełożoną generalną przybyłą z Polski (zob. Kronika, sygn. 6 [1988], s. 13).

${ }^{26}$ Zob. Kronika, sygn. 7 [1989], s. 13.

${ }^{27}$ W 1987 r. było to $11 \%$, w 1988 - 12\%, w $1991-13 \%$. Odsetek zmniejszył się w dwóch kolejnych analizowanych latach do 4\% w 1992 i 8\% w 1995 r. 
stały odsetek pątników zamieszkiwał Dolną Saksonięe ${ }^{28}$. Stosunkowo liczni bywali pątnicy wywodzący się z Hesji ${ }^{29}$ i Bremy $^{30}$, w mniejszym stopniu z Bawarii, Hamburga, Szlezwiku-Holsztyna, Badenii-Wirtembergii czy Zachodniego Berlina ${ }^{31}$. Uczestnicy pieszych pielgrzymek z Essen do Neviges zamieszkiwali zatem wszystkie kraje związkowe dawnych Niemiec Zachodnich. Patrząc przez pryzmat miejscowości okazuje się, że przyjeżdżali do Essen z kilkudziesięciu niemieckich miast. Wielu pielgrzymów było z samego Essen, najliczniej reprezentowanego w 1988 r., bądź sąsiedniego Bochum, z którego pochodziło najwięcej osób w czasie pielgrzymki z 1987 r. W pozostałych omawianych latach najliczniejsze grupy pątników wywodziły się z Berlina Zachodniego (1991), z Duisburga (1992) oraz z Gelsenkirchen (1995). Niestety, dla innych lat brak w zachowanej dokumentacji tak szczegółowych informacji.

Ciekawe dane możemy uzyskać dla roku 1987. W spisach pielgrzymów organizatorzy prosili uczestników o podanie wieku. Przeciętny pielgrzym miał nieco ponad 23 lata. Średnia wieku kobiet wynosiła 21 i pół roku, z kolei przeciętny mężczyzna liczył nieco ponad 24 lata. Te dane z jednego roku potwierdzają, że na szlak pątniczy wyruszała przede wszystkim młodzież. Z grupy 69 osób, których wiek podano, aż 53 liczyły między 12 a 35 lat. Oczywiście zdarzały się osoby dużo młodsze i dużo starsze. W 1987 r. najmłodsza osoba miała 8 lat, a najstarsza 60 , ale nie była to jeszcze największa różnica wiekowa. Z listu do uczestników po zakończeniu pielgrzymki z 1988 r. dowiadujemy się, że najmłodszym uczestnikiem był liczący 6 tygodni Jan Jakub. To oczywiście był wyjątek, ale w tym roku do najmłodszych pątników należeli również dwuletni Beniamin i czteroletnia Ania z Frankfurtu oraz również czteroletni Marcin z Lünnen. Do seniorów należeli 61-letni Józef z Bochum oraz 58-letni Augustyn z Münster ${ }^{32}$.

W tym miejscu warto zadać pytanie, skąd wyruszali pielgrzymi i którędy biegła trasa do Neviges? Z relacji Cezarego Lisa wynika, że pierwsza pielgrzymka w 1981 r. wyruszyła z położonej na południu Essen dzielnicy Kettwig.

${ }^{28}$ Odpowiednio było to: 8\% w 1987, 7\% - w 1988, 13\% - w 1991, 11\% - w 1992 i 4\% - w 1995.

${ }^{29}$ W 1988 r. było to $9 \%$, w $1991-3 \%$, w $1992-10 \%$, w $1995-6 \%$.

${ }^{30}$ W 1991 i 1995 r. pielgrzymi z tego landu stanowili 7\%, w 1988 - 5\%, a w 1991 i $1992-4 \%$.

${ }^{31}$ Odsetek uczestników z tych landów wahał się. Były lata, gdy sięgał nawet $10 \%$, jak w przypadku Berlina w 1991 r., kiedy w pielgrzymce wzięła udział liczna 20-osobowa grupa pątników, czy też Bawarii w 1987 i 1988 r. i z Hamburga w 1991 r., gdy odsetek uczestników zamieszkujących te landy stanowił 7\% pielgrzymów. Były jednak lata, gdy pielgrzymi z tych krajów związkowych nie brali udziału w pielgrzymce lub też ich odsetek wśród całości pątników sięgał 2-3\% ogółu.

${ }^{32}$ Zob. Kronika, sygn. 6 [1988], s. 33. 
Nie wiadomo dokładnie, jak szli nieliczni jeszcze wówczas pielgrzymi, ale z dokumentacji wynika, że trasa przebiegała przez pola, a pątnicy szli często na tzw. azymut, szukając właściwej drogi ${ }^{33}$. W kolejnych latach wyruszano już prawdopodobnie z Eibergu - południowo-wschodniej dzielnicy Essen ${ }^{34}$. Natomiast w 1984 r. na ulotce zapraszającej na coroczną Pielgrzymkę Polską do Neviges organizowaną przez Księży Chrystusowców pojawiła się dodatkowa informacja, że z Essen idzie również piesza grupa pielgrzymów, określona już jako młodzież oazowa. Wówczas grupa wyruszała z Blücherstraße 20 w Essen, gdzie mieścił się Dom Polskiej Misji Katolickiej ${ }^{35}$. Od 1985 r. pielgrzymi już na pewno wyruszali z kościoła pw. Trójcy Świętej, który znajdował się w dzielnicy Eiberg w Essen przy ul. Schultenweg $135^{36}$. Podobnie było w latach 1986, 1987, 1988, 1989, 1991, 1993, 1994, 1995, 1997, 1999, 2001 i 2005 ${ }^{37}$. Jedynie w 1990 i 1992 r. na ulotkach informacyjnych zapisano, że pielgrzymi powinni gromadzić się na mszę św. w kościele „Heilige Dreifaltigkeit - Pfarrzentrum” przy ul. Albert-Schweizer Straße $2^{38}$. W tych latach zatem wyruszano $\mathrm{z}$ centrum parafialnego, które mieści się w odległości $1 \mathrm{~km}$ od samej świątyni. Większość dokumentacji z poszczególnych lat nie zawiera informacji o dokładnej trasie przebiegu. Wiadomo, że w 1986 r. pielgrzymi szli przez Langenberg, zwiedzając wcześniej ruiny zamku w Isenburgu nad Ruhrą ${ }^{39}$. Z 1988 i 1989 r. posiadamy dokładniejsze informacje o trasie pielgrzymki. Zapewne podobnie było również $\mathrm{w}$ kolejnych latach. $Z$ zachowanych materiałów archiwalnych wynika, że pątnicy wyruszali z Eibergu idąc ulicami Schultenweg, Stalleickweg do Dahlhausen (południowo-zachodniej dzielnicy Bochum), gdzie przy cmentarzu zatrzymywano się na pierwszy postój. Tutaj grupa podzieliła się na 50-osobowe

\footnotetext{
${ }^{33}$ Por. Relacja Cezarego Lisa, 16 lutego 2021 r.; Kronika, sygn. 1 [1981], s. 2.

${ }^{34}$ Tak wynika z informacji uzyskanych od Cezarego Lisa, lecz nie ma to jednoznacznego potwierdzenia w zachowanej dokumentacji (zob. Kronika, sygn. 18, s. 76).

${ }^{35}$ Zob. Kronika, sygn. 2 [1983-1984], s. 3.

${ }^{36}$ Świadczą o tym informacje zachowane w archiwaliach przekazanych przez Cezarego Lisa. Zob. Kronika, sygn. 4 [1985], s. 2. Obecnie kościół parafialny w Essen-Eiberg już nie istnieje. 2 maja 2009 r. odprawiono tam ostatnią Mszę św. Decyzją kurii diecezjalnej w Essen świątynia została sekularyzowana i przekształcona w budynek mieszkalny wraz z kawiarnią, miejscem spotkań i salą refleksji, w której zgromadzono również niektóre sprzęty z dawnego kościoła (zob. Gedenktafel Pfarrkirche Hl. Dreifaltigkeit, https://eiberg-heimatgeschichtskreis.de/blog/151/ gedenktafel+pfarrkirche+hl.+ dreifaltigkeit [dostęp: 23.03.2021]).

${ }^{37}$ Kronika, sygn. 4 [1986], s. 10; sygn. 5 [1987], s. 6; sygn. 6 [1988], s. 6; sygn. 7 [1989], s. 6; sygn. 9 [1991], s. 2; sygn. 11 [1993], s. 1; sygn. 12 [1994], s. 2; sygn. 13 [1995], s. 4; sygn. 14 [1997], s. 3; sygn. 15 [2001], s. 1; sygn. 16 [2001], s. 1; sygn. 17 [ 2005], s. 3.

${ }^{38}$ Por. Kronika, sygn. 8 [1990], s. 3; sygn. 10 [1992], s. 7.

${ }^{39}$ Zob. Kronika, sygn. 4 [1986], s. 12, 13.
} 
podgrupy przechodząc przez miasto. Następnie zmierzano w kierunku dworca kolejowego i dalej Lewackerstraße do mostu na rzece Ruhr. W tym miejscu grupy ponownie łączyły się w jedną kolumnę, zmierzając lewym brzegiem rzeki. Drugi postój w tzw. Miejscu Pojednania był w miejscowości Nierenhof przy pomniku wojennym upamiętniającym niemieckich żołnierzy pochodzących z miejscowości i poległych w czasie obu wojen światowych. Następnie pielgrzymi, po przejściu przez Langenberg, zatrzymywali się na polanie za miastem na trzeci i ostatni postój przed dojściem do Neviges. Stąd trasa pielgrzymki musiała wieść już wzdłuż ulic Hohlstraße i zapewne Alaunstraße przez Donnenberg (dzielnicę Velbert) bezpośrednio do sanktuarium w Neviges $^{40}$. Taką trasę potwierdza dokumentacja z $1995 \mathrm{r}^{41}$, materiał roboczy do folderu przygotowywanego na jubileuszową 25 pieszą pielgrzymkę z $2005 \mathrm{r}$. (folder niestety nie zachował się w dokumentacji) ${ }^{42}$, a także zachowane mapki poglądowe ${ }^{43}$.

Należy jeszcze raz podkreślić rolę Cezarego Lisa, inicjatora pieszego pielgrzymowania $z$ Essen do Neviges i wieloletniego organizatora tych peregrynacji. Znaczący udział w rozwoju inicjatywy miał również ks. Kazimierz Ćwierz, ale także całe środowisko oazowe z Carlsbergu. Warto też dodać, że po przeprowadzce C. Lisa z Essen do Ahaus aktywnie do organizacji pieszych pielgrzymek z Essen od 1994 r. włączyła się rodzina Łodzińskich z Essen ${ }^{44}$.

Zrozumiałe jest, że wraz z liczbą uczestników zmieniała się również organizacja pielgrzymki. Z charakteru niejako prywatnego stopniowo nabiera ona większego rozmachu. Jak wspomniano wyżej, od 1985 r., gdy stała się ona pielgrzymką Ruchu Światło-Życie, nabierała charakteru coraz bardziej powszechnego i ogólnodostępnego. Dobrze pokazują to akta Kroniki. Bez wątpienia już w trakcie pierwszych trzech lat pieszego pielgrzymowania była wstępnie określona marszruta wędrówki, terminarz i czas dojścia do Neviges. Co więcej, jak wynika z archiwaliów, cztery pierwsze piesze peregrynacje zaczynały się nocą, a uczestnicy docierali do Neviges bezpośrednio na oficjalne uroczystości związane z coroczną polską pielgrzymką organizowaną

\footnotetext{
${ }^{40}$ Zob. Kronika, sygn. 6 [1988], s. 15; sygn. 7 [1989], s. 8.

${ }^{41}$ Zob. Kronika, sygn. 13 [1995], s. 31.

${ }^{42}$ Zob. Kronika, sygn. 17 [2005], s. 11.

${ }^{43}$ Zob. Kronika, sygn. 18, s. 68.

${ }^{44}$ Chodzi w tym przypadku o Tomasza Łodzińskiego z Essen, jego rodziców, Jerzego i Annę, oraz brata Wojciecha. Zob. Kronika, sygn. 12 [1994], s. 1; sygn. 13 [1995], s. 5, 13; C. Lis, Piesze pielgrzymowanie do Neviges, https://cezarylis.pl/25-piesze-pielgrzymowanie-do-neviges/ [dostęp: 9.04.2021].
} 
przez Księży Chrystusowców. W niedzielę rano piesi pielgrzymi idący z Essen dołączali do polskich pielgrzymów, którzy docierali do sanktuarium samochodami, autobusami lub koleją. Pątnicy, choć jeszcze nieliczni, szli zapewne $\mathrm{z}$ modlitwą na ustach i jak pokazują zdjęcia, z polskimi flagami. Jednak w małej, znającej się grupie osób, plany nie musiały być ścisłe i organizacyjnie do końca dopięte ${ }^{45}$.

W dokumentacji z 1985 r. widzimy już coraz bardziej sformalizowane formy pielgrzymowania. Jest to związane z zaangażowaniem się Ośrodka w Carlsbergu. Zostaje opracowana ulotka pieszej pielgrzymki zawierająca informacje wstępne, a także program. Zgodnie z nim pielgrzymi mieli gromadzić się w sobotę 15 czerwca od godz. 10 w kościele Trójcy Świętej w Essen-Eiberg. O godz. 11 następował wymarsz poprzedzony modlitwą. Około godz. 18-19 planowane było przybycie do Neviges i wspólny posiłek, zaś o godz. 20 nabożeństwo pojednania oraz modlitwa. Spoczynek przewidziano o godz. 22. W niedzielę piesi pielgrzymi rozpoczynali dzień Godzinkami ku czci Najświętszej Maryi Panny o 7:30, o 8:30 było śniadanie, zaś o 9:30 rozpoczynały się oficjalne uroczystości związane z Pielgrzymką Polską do Neviges. Z ulotki wynika również, że zgłoszenia na pielgrzymkę przyjmował ks. K. Ćwierz, wówczas przebywający w Carlsbergu ${ }^{46}$. W dokumentacji z tego roku, obok fotografii ukazujących pielgrzymów w drodze, pojawiają się również prośby i intencje zapisane na karteczkach, z którymi uczestnicy szli do Matki Bożej. Co więcej, został opracowany śpiewnik pielgrzymkowy wykorzystywany zapewne przez grupę muzyczną z gitarami. Pielgrzymi nieśli krzyż, maryjne emblematy i polskie flagi.

Dokumentacja archiwalna $\mathrm{z}$ kolejnych lat świadczy o dalszym organizacyjnym rozwoju pieszego pielgrzymowania na trasie Essen-Neviges. Z przygotowań organizacyjnych do pielgrzymki z 1986 r. zachowały się po raz pierwszy pisane ręcznie notatki, sporządzone zapewne na etapie przygotowań organizacyjnych. Na początku są informacje zatytułowane „Nabożeństwo wyjścia"47, a w dalszej części notatki znajdujemy te dotyczące spraw organizacyjnych $^{48}$ oraz związanych z programem modlitw w drodze ${ }^{49}$.

${ }^{45}$ Tak wynika z relacji fotograficznej i opisów fotografii umieszczonych w dokumentacji. Zob. Kronika, sygn. 1 [1981], s. 2-3.

${ }^{46}$ Kronika, sygn. 3 [1985], s. 2-3.

${ }^{47} \mathrm{~W}$ trakcie nabożeństwa przed wyjściem pielgrzymów z Essen należało poruszyć cztery istotne punkty określające, czym jest piesza pielgrzymka. Po pierwsze - organizatorzy zwracali uwagę, że pielgrzymka piesza to czas rekolekcji, czas, który każdy z pielgrzymujących sobie wyznaczył, oraz że pielgrzymka to wspólne dzieło uczestników. Po drugie - pielgrzymujący tworzą jedną rodzinę, mówią zatem do siebie bracie, siostro lub nawet po imieniu. Po trzecie - pielgrzymka jest ofiarą, zatem piel- 
Zebrane materiały archiwalne potwierdzają, że plany zapisane w notatkach były realizowane. Od 1985 r. niemal co roku w dokumentacji znajdujemy śpiewniki, a także opracowane ulotki informacyjne o pieszej pielgrzymce. Pojawiają się zapisane na karteczkach intencje, rozważania tajemnic różańcowych, konspekty homilii wygłaszanych na mszy inicjującej peregrynację i notatki, zapiski ważnych informacji organizacyjnych do przekazania pielgrzymom. Na fotografiach widać niesione symbole religijne, emblematy oazowe, polskie flagi, a także głośniki i tuby, animatorów muzycznych i śpiewających pielgrzymów. Z kolei w 1987 r. pojawia się po raz pierwszy szczegółowa lista uczestników pielgrzymki, zawierająca imię i nazwisko, dane teleadresowe oraz rubrykę informującą, skąd z Polski pochodzili biorący udział $\mathrm{w}$ pielgrzymce pielgrzymi ${ }^{50}$. W kolejnych latach organizatorzy przygotowali podsumowanie, które rozsyłali do wszystkich uczestników. Prosili o uwagi na temat organizacji i przebiegu, tak by lepiej przygotować się w kolejnym roku. Dziękowali za aktywny udział w modlitwach i śpiewach, za ofiarność, dzięki której udało się pokryć koszty zakupu sprzętu radiofonicznego. Zaczęto również nagrywać film z pielgrzymki. Po zmontowaniu istniała możliwość zakupu kasety $\mathrm{VHS}^{51}$. O rozwoju inicjatywy w kolejnych latach świadczą też listy adresowane m.in. do duchowieństwa niemieckiego ${ }^{52}$, periodyków polskich $\mathrm{z}$ informacją o pielgrzymce ${ }^{53}$ czy też

grzymi winni cierpliwie znosić niewygody, być zdyscyplinowani. I po czwarte - pielgrzymka to czas modlitwy, zbliżenia się do Boga, a nie wycieczka. Stąd należało zachęcać pielgrzymów do aktywnego udziału w modlitwach, spowiedzi w drodze. Zob. Kronika, sygn. 4 [1986], s. 6-8.

${ }^{48}$ Omawiano sprawy noclegów w Domu Pielgrzyma w Neviges, jak też w samym Essen dla osób przyjeżdżających na pielgrzymkę, a także zaopatrzenia w żywność na przewidywaną kolację po dojściu do Neviges. Istotna była kwestia wozu transportującego bagaże pielgrzymów, nagłośnienie w postaci tub i mikrofonów, nagrania wideo. Poruszano tematykę śpiewnika i głównego animatora muzycznego, krzyża pielgrzymkowego, proporców maryjnych, polskich flag, emblematów oazowych oraz stoiska z materiałami. Zob. tamże.

${ }^{49}$ Przewidywano rozważania różańcowe, Drogę krzyżową, śpiewanie Litanii do NMP, konferencje pt. „Idea pielgrzymowania w Biblii”, modlitwę próśb. Pomyślano również o tzw. kwadransie dla bliźniego i oczywiście możliwości spowiedzi. Zob. tamże.

${ }^{50}$ Zob. Kronika, sygn. 5 [1987], s. 20-23.

${ }^{51}$ Zob. Kronika, sygn. 6 [1988], s. 33-34.

${ }^{52}$ Przykładowo - z 1990 r. list zapraszający do ks. Lauera, proboszcza parafii pw. Trójcy Świętej w Essen, skąd wyruszała pielgrzymka. Ponadto korespondencja z o. Hubertusem Hartmannem OFM, przełożonym oo. franciszkanów opiekujących się sanktuarium w Neviges (Kronika, sygn. 8 [1990], s. 10-12, 16-18). Z kolejnych lat korespondencja z kurią w Essen, w Fuldzie czy też w Hildesheim (tamże, sygn. 13 [1995], s. 47-49), ale wiadomo, że kontaktowano się z ośmioma innymi niemieckimi biskupstwami w sprawie dofinansowania pielgrzymki (zob. tamże, s. 52).

${ }^{53}$ Zachowała się korespondencja do redakcji „Naszego Słowa” z Würzburga. Zob. Kronika, sygn. 13 [1995], s. 45-46. 
korespondencja z instytucjami niemieckimi ${ }^{54}$. Z kolei dla roku 1995 zachowały się dokładne dokumenty prezentujące wyliczenia planowanych kosztów i zrealizowanych wydatków, co potwierdza bez wątpienia systematyczny wzrost organizacyjny pieszego pielgrzymowania z Essen ${ }^{55}$.

Reasumując, piesze pielgrzymowanie $z$ Essen do sanktuarium maryjnego w Neviges zainicjowane w 1981 r. przez Cezarego Lisa weszło w tradycję polonijnych środowisk w Niemczech. Pomysł przyjął się dobrze, choć nie od razu. Z niejako kameralnej, niedużej imprezy pielgrzymka stopniowo przekształciła się w wydarzenie ważne i znaczące dla wielu Polaków zamieszkujących Niemcy, szczególnie od chwili, gdy włączona została w działania duszpasterskie Ruchu Światło-Życie w Niemczech. Ten fakt nie tylko sprzyjał organizacyjnemu rozwojowi esseńskiej peregrynacji, ale nadał jej nowy rys, wpisując niejako w oazową duchowość tak dobrze znaną wielu Polakom w kraju. Nie sposób jednak opisać w tekście spontanicznej atmosfery, kłopotów technicznych ze sprzętem nagłaśniającym, problemów organizacyjnych np. z noclegami dla coraz liczniejszej grupy pielgrzymów. Te aspekty na pewno były obecne, podobnie jak serdeczność i nawiązywanie przyjaźni między pielgrzymami. Nie sposób oddać też w pełni atmosferę modlitwy, radości, szacunku i głębokiej wiary uczestników rekolekcji w drodze. W pewien, choć przecież ułomny sposób przekazują to tylko zachowane liczne fotografie.

Dzieło okazało się trwałe. Wprawdzie obecnie pielgrzymka nie wyrusza już z kościoła pw. Trójcy Świętej w Essen, gdyż świątynia została sekularyzowana. Nie jest również prowadzona przez Ruch Światło-Życie, lecz przez Polską Misję Katolicką w Niemczech - parafię polską w Essen. Jednak do dzisiaj Polacy w Niemczech pielgrzymują pieszo na trasie Essen-Neviges,

\footnotetext{
${ }^{54} \mathrm{~W}$ dokumentacji są np. listy do jednostek miejskich w Essen (Kronika, sygn. 8 [1990], s. 14-15), Velbert (tamże, s. 19-20; sygn. 13 [1995], s. 56) czy Wuppertalu (tamże, sygn. 6 [1988], s. 15-17).

${ }^{55}$ Przykładowo organizatorzy pieszej peregrynacji w 1995 r. przewidywali łączne wydatki w wysokości 1290 marek. Planowano wydatki na wykonanie ulotki informacyjnej (300 marek), na publikację ogłoszenia w „Naszym Słowie” (50 marek), wykonanie drogowskazów (30 marek), wynajęcie mikrobusa do transportu bagaży i wody (150 marek), zakup wody i kubków (80 marek), zakup worków na śmieci (10 marek), wykonanie planszy na kiju do niesienia na trasie (50 marek), koszty związane z zakupem baterii do nagłośnienia (50 marek), z wynajęciem sali gimnastycznej (70 marek), z wykonaniem ulotki o Ruchu Światło-Życie oraz terminarza rekolekcji oazowych (500 marek). Ostatecznie z zachowanego rozliczenia wynika, że pobrano łącznie od 163 uczestników 815 marek, z czego wydano 709,41. Od każdego uczestnika pobierano 5 marek. Zrealizowane wydatki obejmowały np. kopie kolorowych znaczków pielgrzymkowych, druk ulotek, wynajęcie nagłośnienia, przygotowanie transparentów, prace porządkowe w salach sportowych, w których pielgrzymi nocowali. Zob. Kronika, sygn. 13 [1995], s. 10-13.
} 
a kolejne peregrynacje liczone są od tej pierwszej nocnej pielgrzymki siedmiu osób sprzed 40 lat.

\section{BIBLIOGRAFIA}

\section{Źródła}

Archiwum Główne Ruchu Światło-Życie

zespół: Spuścizna archiwalna Cezarego Lisa, seria: Kronika pieszej pielgrzymki Essen-Neviges 1981-2005, sygn. 1-18

\section{Opracowania}

GRYGIEL M. TCHR, Sanktuaria Maryjne na szlakach pielgrzymich Polonii, [w:] Bogurodzica na ludzkich drogach życia, red. B. Walicki, Sokołów Małopolski: Wimaart 2010, s. 201-216.

HaUN G., Mariendom Neviges, Lindenberg: Kunstverlag Josef Fink 1997.

HAUN G., Die Wallfahrt nach Neviges, Wuppertal: Frohn 1981.

JABŁoŃSKI S., Pielgrzymka, III. W chrześcijaństwie, [w:] Encyklopedia Katolicka, t. XV, Lublin: TN KUL 2011, kol. 485-491.

MurzYNowsKa K., Polskie wychodźstwo zarobkowe w zagłębiu Ruhry w latach 1880-1919, Wrocław: Ossolineum 1972.

PAŁUBSKa Z., Pielgrzymowanie, [w:] Encyklopedia Katolicka, t. XV, Lublin: TN KUL 2011, kol. 501.

Wesoly K., Velbert, Neviges und Langenberg vom früher Mittelalter bis zum Ende bergischen Zeit (1806), [w:] Velbert - Geschichte dreier Städte, Hrsg. H. Degen, Ch. Schotten, Köln: J.P. Bachem 2009, s. 18-98.

Wohlmann W., Die neue Stadt Velbert (1975-2008), [w:] Velbert - Geschichte dreier Städte, Hrsg. H. Degen, Ch. Schotten, Köln: J.P. Bachem 2009, s. 482-538.

\section{Netografia}

Gedenktafel Pfarrkirche Hl. Dreifaltigkeit, https://eiberg-heimatgeschichtskreis.de/blog/151/ gedenktafel+pfarrkirche+hl.+dreifaltigkeit [dostęp: 23.03.2021].

LIS C., Piesze pielgrzymowanie do Neviges, https://cezarylis.pl/25-piesze-pielgrzymowanie-doneviges/ [dostęp: 9.04.2021].

Mariendom „Maria, Königin des Friedens“, https://www.wallfahrt-neviges.de/index.php/wallfahrt /mariendom [dostęp: 10.03.2021].

Paszek L., Historia Polskiej Misji Katolickiej w Essen, http://www.pmk-essen.de/index2. php?id=historia [dostęp: 24.03.2021].

Piesza Pielgrzymka Polaków do Neviges, https://www.chrystusowcy.pl/piesza-pielgrzymka-polakow -do-neviges [dostęp: 10.03.2021]. 


\title{
POLSKIE PIESZE PIELGRZYMKI \\ Z ESSEN DO NEVIGES W LATACH 1981-2005
}

\author{
Streszczenie
}

W polskiej obyczajowości piesze pielgrzymki do sanktuariów maryjnych są charakterystycznym znakiem religijności. Jednym z przykładów nawiązania do tej wielowiekowej polskiej obrzędowości jest inicjatywa rozpoczęta w 1981 r. w środowisku polskiej młodzieży skupionej przy Polskiej Misji Katolickiej w Essen.

Podstawę źródłową artykułu stanowi dokumentacja archiwalna zgromadzona w Archiwum Głównym Ruchu Światło-Życie w Lublinie. Seria akt dotycząca tych peregrynacji obejmuje 18 teczek aktowych z lat 1981-2005.

Inicjatywa miała początkowo charakter prywatny, ale z kolejnymi latami stopniowo nabierała coraz większego rozmachu. Od 1985 r. do jej organizacji włączyło się środowisko oazowe z Carlsbergu w Nadrenii Palatynacie skupione wokół ks. Franciszka Blachnickiego. Nastąpił wówczas intensywny rozwój organizacyjny pielgrzymki. Ruch Światło-Życie przejął duchową opiekę nad pielgrzymami, których liczba rosła w kolejnych latach.

Uczestnicy pieszych peregrynacji pochodzili z wszystkich zachodnioniemieckich landów. Przeważała młodzież, choć brali w nich udział także osoby starsze, a nawet kilkuletnie dzieci. Pątnicy wyruszali najczęściej z parafii Świętej Trójcy w Eiberg-Essen. Przemierzali zachodnie dzielnice Bochum (Dalhausen), następnie Nierenhof i Langenberg, docierając do sanktuarium w Neviges od strony wschodniej. Na miejsce przybywali w sobotę, zaś w niedzielę dołączali już do ogólnych uroczystości związanych z Polską Pielgrzymką do Neviges organizowaną przez Księży Chrystusowców.

Piesze pielgrzymowanie z Essen do sanktuarium maryjnego w Neviges weszło w tradycję polonijnych środowisk w Niemczech. Kolejne trwające do dzisiaj peregrynacje liczone są od tej pierwszej, zorganizowanej 40 lat temu.

Słowa kluczowe: Neviges; Essen; Polska Misja Katolicka w Niemczech; Polonia w Niemczech; pielgrzymki piesze; Ruch Światło-Życie; ośrodek oazowy w Carlsbergu; oazy w Niemczech; ks. Franciszek Blachnicki

\section{POLISH WALKING TOURS \\ FROM ESSEN TO NEVIGES IN 1981-2005}

\section{Summary}

In Polish tradition, walking pilgrimages to Marian shrines are a typical manifestation of being religious. One example of a reference to this centuries-old Polish ritual is the initiative started in 1981 by Polish youths from the Polish Catholic Mission in Essen.

The article is based on the archival documentation of the Central Archives of the Light-Life Movement in Lublin. The series of files concerning these peregrinations comprises 18 file folders from the years 1981-2005.

At the beginning the initiative was private, but in the years to come it gradually gained momentum. From 1985, its organization was helped by the oasis community from Carlsberg in Rhineland Palatinate, focused around Father Franciszek Blachnicki. It was then that intensive 
organisational growth of the pilgrimage took place. The Light-Life Movement took over the spiritual care of the pilgrims, whose numbers grew in the following years.

The participants came from all the West German länder. Most of them were young people, but there were also older people and even young children. The pilgrims usually set off from the parish of the Holy Trinity in Eiberg (Essen). They walked through the western districts of Bochum (Dalhausen), then through Nierenhof and Langenberg, arriving at the shrine in Neviges from the east on a Saturday, and then on Sunday they joined the general celebrations of the Polish Pilgrimage to Neviges organized by the Priests of Christ.

The pilgrimage on foot from Essen to the Marian shrine in Neviges has become part of the traditions cultivated by the Polish communities in Germany. The pilgrimages are counted from the first one organised 40 years ago.

Keywords: Neviges; Essen; Polish Catholic Mission in Germany; Polonia in Germany; walking pilgrimages; Light-Life Movement; Carlsberg Oasis Centre; oases in Germany; Fr Franciszek Blachnicki 